\title{
An Assessment of the Important Radionuclides in Nuclear Waste
}

\author{
J. F. Kerrisk
}

\section{DISCLAIMER} Govern Neither the United States Government nor any agency ther liability or responsiemployes, makes any warranty, express or impled, of any information, apparatus, product, or bility for the accuracy, completeness, or usefulness of an infringe privately owned rights. Referprocess disclosed, or represents that its use would process, or service by trade name, trademerecomence herein to any specific commercial product, prostitute or imply its endorseren. The views manufacturer, or otherwise doe United States Government or any agency thect those of the

and opinions of authors expressed hered States Government or any agency thereof.

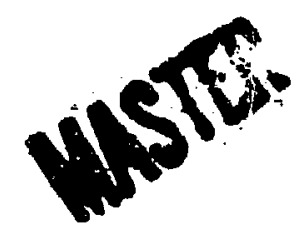


AN ASSESSMENT OF THE IMPORTANT RADIONUCLIDES IN NUCLEAR WASTE

by

J. F. Kerrisk

\begin{abstract}
The relative importance of the various radionuclides contained in nuclear waste has been assessed by consideration of (1) the quantity of each radionuclide present, (2) the Environmental Protection Agency!'s release limits for radionucildes, (3) how retardation processes such as solubility and sorption affect radionuclide transport, and (4) the physical and chemical forms of radionucilides in the waste. Three types of waste were revlewed: spent fuel, high-level waste, and defense high-level waste. Conditions specific to the Nevada Nuclear Haste Storage Investigations project potential site at Yucca Mountain were used to describe radionuclide transport. The actinides $\mathrm{Am}, \mathrm{Pu}, \mathrm{Np}$, and $U$ were identifled as the waste elements for which solubllity and sorption data were most urgently needed. other important waste elements were Identified as Sr, Cs, C, N1, Zr, Tc, Th, Ra, and Sn. Under some conditions, radionuclides of three elements ( $C$, Tc, and I) may have high solubility and negligible sorption. The potential for transport of some waste elements (C and I) in the gas phase must also be evaluated for the Yucca Mountain Site.
\end{abstract}

\title{
I. INTKUDUCTION
}

A program to butld and 1icense a nuclear waste repository must consider the type of waste to be stored and, in particular, the radionucilde composition of the waste over time after storage begins. This information is needed to assess how well the proposed repository will contain the waste over a long time. Presently, there are several different types of waste that might be 
stored at potential repository sites being studied by the office of Civilian Radioactive Waste Management of the Department of Energy. They include spint fuel from bolling water reactors (BWR) or pressurized water reactors (PWR), high-level waste obtained from reprocessing BWR or PWR spent fuel, defense high-level wasce, and transuranic (TRU) waste. The different physical forms and radionuclide compositions of these wastes create different problems in site characterization and performance assessment.

The Nevada Nuclear Waste Storage Investigations project is studying a site at Yucca Mountain in southern Nevada as a potential nuclear waste repository. As part of the geochemical site characterization of Yucca Mountain being done at Los Alamos National Laboratory, questions concerning the relative importance of various radionuclides have arisen in the context of studies of how solubility and sorption on local minerals affect radionuclide transport. In assessing the suitability of the site, those radionuclides that are present in large quantities, that must be contained well, or that present special problems should be given attention early in the program.

This report presents an assessment of the relative importance of radionuclides in various types of nuclear waste. Four factors are considered in this assessment:

1. the quantity of various radionuclides present in the waste,

2. the Environmental Protection Agency (EPA) release limits for the radionuclides,

3. how different retaidation processes such as solubility and sorption might affect radionuclide transport, and

4. the physical and chemical forms of the radionuclides in the waste. Because of the uncertainties about waste types, presenting a single list of radionuclides ordered by relative importance is impossible. However, this report highlights radionuclides that may be important regardless of the waste form and others that may be important under certain conditions.

\section{REPOSITORY INVENTORY}

Before an assessment can be made of the importance of the various radionuclides in nuclear waste, it is necessary to know the radionuclide composition of the waste. For waste from civilian reactors, data from the compilation of Croff and Alexander ${ }^{1}$ were used. The two common types of 1 ight-water reactors 
(PWR and BWR) produce waste (spent fuel and high-level waste) that is suff1clently similar to consider only PWR data in this analysis; conclusions drawn for PWR waste generaily apply to BWR waste also. The PWR-waste data are for fuel that was irradlated at 37.5 MW/MTHM to a burnup of 33000 MHd/MTHM. The unit miHM is metric ton of heavy metal (uranium plus plutonium) originally charged to the reactor. The radloactivity content of the waste is reported in units of $\mathrm{C} 1 / 1000$ MTHM. The spent-fuel waste is composed of fuel, cladding, and structural material from the fuel assembly. 1 High-level waste comes from reprocessed fuel from spent-fuel waste. During reprocessing, $99.5 \%$ of the urantum and plutonium are assumed to be removed from the waste. 0ther fission and activation products may also be isolated at this time for separate storage. For the analysis done here, it was assumed that a repository storing high-level waste would also store fission products segregated during reprocessing along with cladding and structural wastes. Although many of these wastes, cladding and structural wastes in particular, are usually not considered to be part of $h i g h-l e v e l$ waste, they represent highly radioactive materlal generated in the fuel cycle that must be isolated from the environment.

Data for defense high-level waste were obtained from calculations by J. R. Fowler and M. D. Boersma of the Waste Solidification Technology Division of Savannah River Laboratory, Alken, South Carolina. The resuits ${ }^{2}$ give the radionuclide inventory of Savannah River high-level waste from the future Defense Waste Processing Facility. This facility is designed to process alkaline waste sludge that has been stored for 5 years after discharge from a reactor, mixed with cesium concentrate from soluble alkaline waste that has been stored for 15 years, into a borosilicate glass. The radionuclide inventories are reported in terms of the activity or mass of radionuclides per canister of glass $(1480 \mathrm{~kg})$. A conversion between the quantity of waste in a canister and the quantity of heavy metal originally charged to the reactor is not avallable. For the analysis done here, it was assumed that the equivalent loading of defense hign-level waste canisters in MTHM/canister could be estimated from the total activity (ci/canister) of PWR high-level waste and defense high-level waste canisters. PWR high-level waste canisters will contain waste from about 2 MTHH $^{3}$ with about $70000 \mathrm{Cl} / \mathrm{Canister} 100$ years after discharge. 1 Defense high-level waste canisters will contain about $16000 \mathrm{Ci} / \mathrm{canister} 100$ years after discharge. Based on an equivalence of the curie content, the loading of defense high-level waste canisters would be about 
$0.5 \mathrm{MTHM} / \mathrm{canister}$. This assumption does not affect the relative importance of radionuclides within a given waste type; it does, however, make comparisons between PWR waste and defense waste somewhat uncertain.

TRU wastes, wilch contain alpha-emitting transuranic radionuclides at levels generally lower than high-level waste, may also be stored in a geologic repository, but they were not specifically considered in this analysis. Presently, the amount of TRU waste that might be stored in a repository and the radionuclide inventory of that waste are uncertain. The radionucilides in TRU waste are generally also present in high-level waste; thus, no new important radionuclides should be added from TRU waste. One important aspect of TRU waste that may influence radionuclide transport is the presence of other materials such as organics. ${ }^{4}$ The effect of these other materials on wasteelement speciation and solubility must be investigated if a decision is made to store TRU waste in a geulogic repository.

Table I is a list of the total inventory in C1/1000 MTHM for the various types of waste considered here. The inventory is divided into activation products, fission produrts, and actinides for civilian waste. 1 Throughout an important perlod (1000 to 10000 years) for the effects of geochemical processes on radionucilde transport, the inventory from PWR spent fuel is about an order of magnitlide larger than from PWR high-level waste. Thus, spent fuel preserits a more difficult containment problem.

More significant for identifying important radionuclides is the identity of the radionuclides that contribute most to the inventory over time. Tables II, III, and IV Iist the primary radionuclides and the amounts they contribute to the total inventory of the waste for PWR spent fuel, PWR highlevel waste, and defense high-level waste, respectively. The actinides and their decay products are represented by 1sotopes of $\mathrm{Np}, \mathrm{U}, \mathrm{Pu}, \mathrm{Am}, \mathrm{Cm}, \mathrm{Th}$, $\mathrm{Ra}$, and $\mathrm{Pa}$. The radionuclides ${ }^{137} \mathrm{Cs},{ }^{90} \mathrm{Sr},{ }^{99} \mathrm{Tc},{ }^{126} \mathrm{Sn},{ }^{135} \mathrm{Cs},{ }^{151} \mathrm{Sm}$, ${ }^{79} \mathrm{Se}$, and their short-lived daughters are fission products. The radionuclide ${ }^{93} \mathrm{Zr}$ is both a fission product and PWR cladding activation product. other cladding activation products are ${ }^{63} \mathrm{N1}$ and ${ }^{59} \mathrm{N1}$. The radionuclide ${ }^{14} \mathrm{C}$ comes primarily from activation of ${ }^{14} \mathrm{~N}$, which is present in both PWR fuel and cladding. The ${ }^{14} \mathrm{C}$ content of defense high-level waste is insignificant. ${ }^{2}$ The fission product ${ }^{129_{I}}$ is generally considered important, but it does not appear in Tables II, III, and IV because it does not contribute significantly to the total inventory of the waste; ${ }^{129} 1$ will be discussed 
REPOSITORY INVENTORY FOR VARIOUS TYPES OF NUCLE'́n SASTE

C1/1000 MTHM for Vartous Decay Times

$10^{2}$ year $10^{3}$ year $10^{4}$ year $10^{5}$ year

PWR Spent Fuel

Activation products

$3.2 \times 10^{5}$

$8.4 \times 10^{3}$

$6.4 \times 10^{3}$

$2.5 \times 10^{3}$

Actinides

$6.8 \times 10^{6}$

$1.7 \times 10^{6}$

$4.4 \times 10^{5}$

$3.9 \times 10^{4}$

Fission products

$3.4 \times 10^{7}$

$1.9 \times 10^{4}$

$1.9 \times 10^{4}$

$1.4 \times 10^{4}$

Total

$4.1 \times 10^{7}$

$1.8 \times 10^{6}$

$4.7 \times 10^{5}$

$5.6 \times 10^{4}$

PliR High-Level Waste

Activation products

$3.2 \times 10^{5}$

$8.4 \times 10^{3}$

$6.4 \times 10^{3}$

$2.5 \times 10^{3}$

Actinides

$3.2 \times 10^{5}$

$8.3 \times 10^{4}$

$2.0 \times 10^{4}$

$2.5 \times 10^{3}$

Fission products

$3.4 \times 10^{7}$

$1.9 \times 10^{4}$

$1.9 \times 10^{4}$

$1.4 \times 10^{4}$

Total

$3.4 \times 10^{7}$

$1.1 \times 10^{5}$

$4.5 \times 10^{4}$

$1.9 \times 10^{4}$

Defense High-Level Waste

Total

$3.2 \times 10^{7}$

$6.0 \times 10^{4}$

$3.1 \times 10^{4}$

$1.7 \times 10^{4}$

In Sec. VII because of its high solubility and poor sorption behavior. Some radionuclides listed in Tables II, III, and IV have relatively short half-lives and would not be important in a study of transport mechanisms. At 100 years after discharge. ${ }^{137} \mathrm{Cs},{ }^{90} \mathrm{Sr}$, and their short-lived daughters dominate the inventory for all types of waste. By 1000 years after discharge, the actinides are the predominant radionuclides. At 10000 and 100000 years, activation products, fission products, and actinides are all important, although the actinides are more important for spent fuel than for high-level waste.

\section{EPA LIAITS}

The total activity of the various radionucildes present is only part of the measure of their importance. In response to the Nuclear Waste Policy Act, the EPA is developing a standard for nuclear waste repositories. ${ }^{5}$ In its 
PRIMARY RADIONUCLIDES CONTRLBUTINGG TO REPOSITORY INVENTORY FOR PWR SPENT FUEL

Radionuclide and Per cent of Total Activity for Varlous Decay Times

\begin{tabular}{|c|c|c|c|c|c|c|c|}
\hline \multicolumn{2}{|c|}{$10^{2}$ year } & \multicolumn{2}{|c|}{$10^{3}$ year } & \multicolumn{2}{|c|}{$10^{4}$ year } & \multicolumn{2}{|c|}{$10^{5}$ year } \\
\hline${ }^{13} 7_{C S}$ & $25 x$ & ${ }^{241} \mathrm{Am}$ & 518 & ${ }^{239} \mathrm{Pu}$ & $51 \%$ & ${ }^{239} \mathrm{Pu}$ & $33 \%$ \\
\hline $137 \mathrm{~m}_{\mathrm{Ba}}$ & $24 x^{a}$ & ${ }^{240} \mathrm{Pu}$ & $27 \%$ & ${ }^{240} \mathrm{Pu}$ & $39 \%$ & ${ }^{99} \mathrm{Tc}$ & $17 \%$ \\
\hline${ }^{90} \mathrm{Sr}$ & $17 \%$ & ${ }^{239} \mathrm{Pu}$ & $17 \%$ & 99 & $3 \%$ & ${ }^{59}{ }_{N 1}$ & $4 x$ \\
\hline${ }^{90} Y$ & $17 x^{b}$ & ${ }^{243} \mathrm{Am}$ & $0.9 \%$ & ${ }^{243} \mathrm{Am}$ & $1 \%$ & ${ }^{93} \mathrm{Zr}$ & $3 \%$ \\
\hline${ }^{241} \mathrm{Am}$ & $9 x$ & ${ }^{239} \mathrm{~Np}$ & $0.9 \%^{c}$ & ${ }^{239} \mathrm{~Np}$ & $1 x^{c}$ & $93 m_{N b}$ & $3 x^{d}$ \\
\hline${ }^{238} \mathrm{Pu}$ & $3 \%$ & ${ }^{99} \mathrm{TC}$ & $0.7 \%$ & ${ }^{59}{ }_{\mathrm{N}}$ & $1 \%$ & ${ }^{234} \mathrm{U}$ & $3 \%$ \\
\hline${ }^{241} \mathrm{Pu}$ & $2 x$ & ${ }^{59} \mathrm{N1}$ & $0.3 \%$ & ${ }^{234} \mathrm{U}$ & $0.4 \%$ & ${ }^{242} \mathrm{Pu}$ & $3 \%$ \\
\hline${ }^{240} \mathrm{Pu}$ & $1 \%$ & ${ }^{234} \mathrm{U}$ & $0.1 \%$ & ${ }^{93} \mathrm{Zr}$ & $0.4 \%$ & ${ }^{23} I_{\mathrm{Np}}$ & $2 \%$ \\
\hline${ }^{239} \mathrm{Pu}$ & $0.8 x$ & ${ }^{93} \mathrm{Zr}$ & $0.1 \%$ & ${ }^{93} m_{N}$ & $0.4 x^{\mathrm{d}}$ & ${ }^{233} \mathrm{~Pa}$ & $2 x^{e}$ \\
\hline${ }^{63} \mathrm{~N} 1$ & $0.8 x$ & $93 m_{N}$ & $0.1 x^{d}$ & ${ }^{242} \mathrm{Pu}$ & $0.4 \%$ & ${ }^{6} \mathrm{Ra}$ & $2 x^{\dagger}$ \\
\hline${ }^{151} \mathrm{Sm}$ & $0.4 x$ & ${ }^{242} \mathrm{Pu}$ & $0.1 \%$ & $231 \mathrm{~Np}$ & $0.3 \%$ & ${ }^{230} \mathrm{Th}$ & $2 \%$ \\
\hline
\end{tabular}

$10^{3}$ year

$10^{4}$ year

$10^{5}$ year

a Short-11ved daughter of ${ }^{137} \mathrm{Cs}$.

${ }^{b}$ short-lived daughter of ${ }^{90} \mathrm{Sr}$.

'Short-1ived daughter of ${ }^{243} \mathrm{Am}$.

${ }^{d}$ Short-lived daughter of ${ }^{93} \mathrm{Zr}$.

${ }^{\text {e }}$ Short-lived daughter of ${ }^{237} \mathrm{~Np}$.

$f_{\text {Decay products of }}{ }^{226} \mathrm{Ra}$ are in secular equilibrium; each decay product also represents $2 \%$ of inventory. The ${ }^{226}$ Ra decay products are generally short lived.

present form, this standard $11 \mathrm{mits}$ the release of radionuclides to the environment for 10000 years after disposal. Cumulative release 1 imits for radionuclides are prescribed in the standard. Table $v$ ilsts these release limits as presently set. They cover all radioactive isotopes. All alphaemitting radionuclides except ${ }^{230}$ Th and ${ }^{232}$ Th have a release $11 \mathrm{mit}$ of $100 \mathrm{Cl} / 1000$ MTHM. Most radionuclides that do not emit alpha particles have a release limit of $1000 \mathrm{C1} / 1000$ MTHM; the exceptions are ${ }^{14} \mathrm{C}$ and ${ }^{129} \mathrm{I}$, which have lower release $11 \mathrm{mits}$ (100 C1/1000 MTHM) because of their biological activity, and ${ }^{99} \mathrm{TC}$, which has a higher release $11 \mathrm{mit}$ (10 $\left.000 \mathrm{C} 1 / \mathrm{MTHM}\right)$. 
PRIMARY RADIONUCLIDES CONTRIBUTING TO

REPOSITORY INVENTORY FOR DEFENSE HIGH-LEVEL WASTE

Radionuclide and Per cent of Total Activity for Varlous Decay Times

\section{$10^{2}$ year}

${ }^{90} \mathrm{Sr} \quad 25 \%$

${ }^{90} \mathrm{Y} \quad 25 \mathrm{~K}^{\mathrm{a}}$

${ }^{137}$ Cs $24 \%$

$137 \mathrm{~m}_{\mathrm{Ba}} 22 \%^{\mathrm{b}}$

$238 \mathrm{Pu}$

$63_{\mathrm{NI}}$

${ }^{151} \mathrm{Sm}$

241 Am

$241 \mathrm{Pu}$

${ }^{239} \mathrm{Pu}$

$240 \mathrm{Pu}$
$10^{3}$ year

241 Am $31 \%$

$239 \mathrm{Pu} \quad 28 \%$

$240 \mathrm{Pu} \quad 16 \%$

${ }^{59} \mathrm{N1} \quad 6 \%$

${ }^{99} \mathrm{TC} \quad 6 \%$

${ }^{93} \mathrm{Zr} \quad 3 \%$

$93 \mathrm{~m}_{\mathrm{Nb}} \quad 3 x^{\mathrm{c}}$

$234 \mathrm{U}$

$238 \mathrm{Pu}$

${ }^{63} \mathrm{NI}$

${ }^{126} \mathrm{Sn}$
$2 \%$

$1 \%$

$0.6 \%$

$0.4 \%$
$10^{4}$ year

$\begin{array}{rr}{ }^{239} \mathrm{Pu} & 43 \% \\ { }^{240} \mathrm{Pu} & 13 \% \\ { }^{99} \mathrm{TC} & 11 \% \\ { }^{59} \mathrm{N1} & 11 \%\end{array}$

${ }^{93} \mathrm{Zr} \quad 7 \%$

$93 \mathrm{~m}_{\mathrm{Nb}} \quad 7 x^{\mathrm{c}}$

${ }^{234} \mathrm{U} \quad 5 \%$

${ }^{126} \mathrm{Sn} \quad 0.8 \%$

${ }^{79} \mathrm{Se} \quad 0.5 \%$

${ }^{135}$ Cs $0.5 \%$

${ }^{230}$ Th $0.4 \%$
$10^{5}$ year

${ }^{99} \mathrm{rc} \quad 14 \%$

${ }^{93} \mathrm{Zr} \quad 11 \%$

$93 m_{\mathrm{Nb}} 11 \mathrm{x}^{\mathrm{C}}$

${ }^{59}{ }_{\mathrm{N1}} \quad 8 \%$

${ }^{234} \mathrm{U} \quad 6 \%$

${ }^{239} \mathrm{Pu} \quad 6 \%$

${ }^{230} \mathrm{Th} \quad 4 \%$

226 Ra $4 x^{d}$

${ }^{135} \mathrm{Cs} \quad 1 \%$

${ }^{126} \mathrm{Sn} \quad 1 \%$

${ }^{79} \mathrm{Se} \quad 0.4 \%$

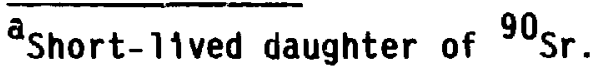

${ }^{b}$ Short-11ved daughter of ${ }^{137} \mathrm{Cs}$.

${ }^{c}$ Short-11ved daughter of ${ }^{93} \mathrm{Zr}$.

doecay products of ${ }^{226} \mathrm{Ra}$ are in secular equilibrium; each decay product also represents $4 \%$ of inventory. The 226 Ra decay products are generally short lived.

Compared with an ordering of radionuclides based on their inventory (see Tables II, III, and IV), the orderings shown in Tables VI, VII, and VIII increase the importance of actinides because they are usually alpha emitters and thus have lower EPA 1 imits. In particular, ${ }^{99} \mathrm{Tc}$, which has the highest release $11 \mathrm{mit}$ of any radionuclide, is reduced from being the major contributor to the inventory of PWR high-level waste at 10000 and 100000 years (see Table III) to a level below many other radionuclides when ordered on the inventory/EPA 11 mitt ratio (see Table VII). 


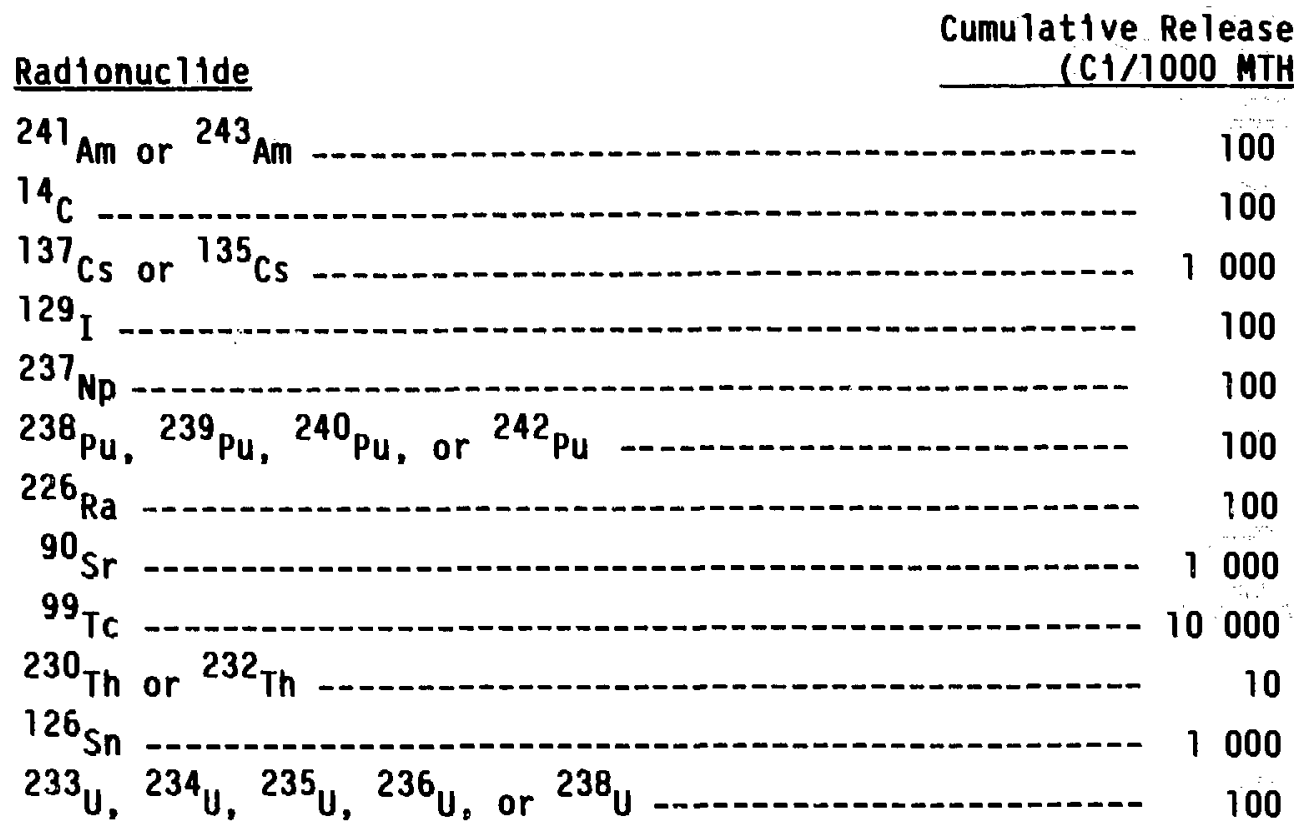

Any other alpha-emitting radionuclide

with a half-11fe greater than 20 years ............. 100

Any other radionuclide with a half-life greater

than 20 years that does not emit alpha particles ----- 1000

\section{EFFECTS OF SOLUBILITY}

The previous discussions have not considered any specific repository site; the orderings listed in Tables VI to VIII would be the same for any site storing the type of waste considered. However, solubility, which depends on water chemistry, has site-dependent effects. A simple model has been developed to assess the effects of solubility on element dissolution from solid waste at the proposed Yucca Mountain repository. ${ }^{6}$ Results from this model can be used to rank radionuclides in terms of the ratio of the radionuclide dissolution rate (C1/1000 MTHM year) to the EPA $11 \mathrm{~m} 1 \mathrm{t}$ ( $\mathrm{C1/1000}$ MTHM). This ratio represents the fraction of the EPA IImit of a given radionucilde that is released from the solid waste each year. The ratio is large for radionuclides with large dissolution rates (radionuclides that are not 11 mited by solubility) and with low EPA release 1 imits. 
RADIONUCLIDES ORDERED BY RATIO OF

INVENTORY TO EPA LIMIT FOR

PWR SPENT FUEL

Radionuclide and (Inventory/EPA Limit) for Vartous Decay Times

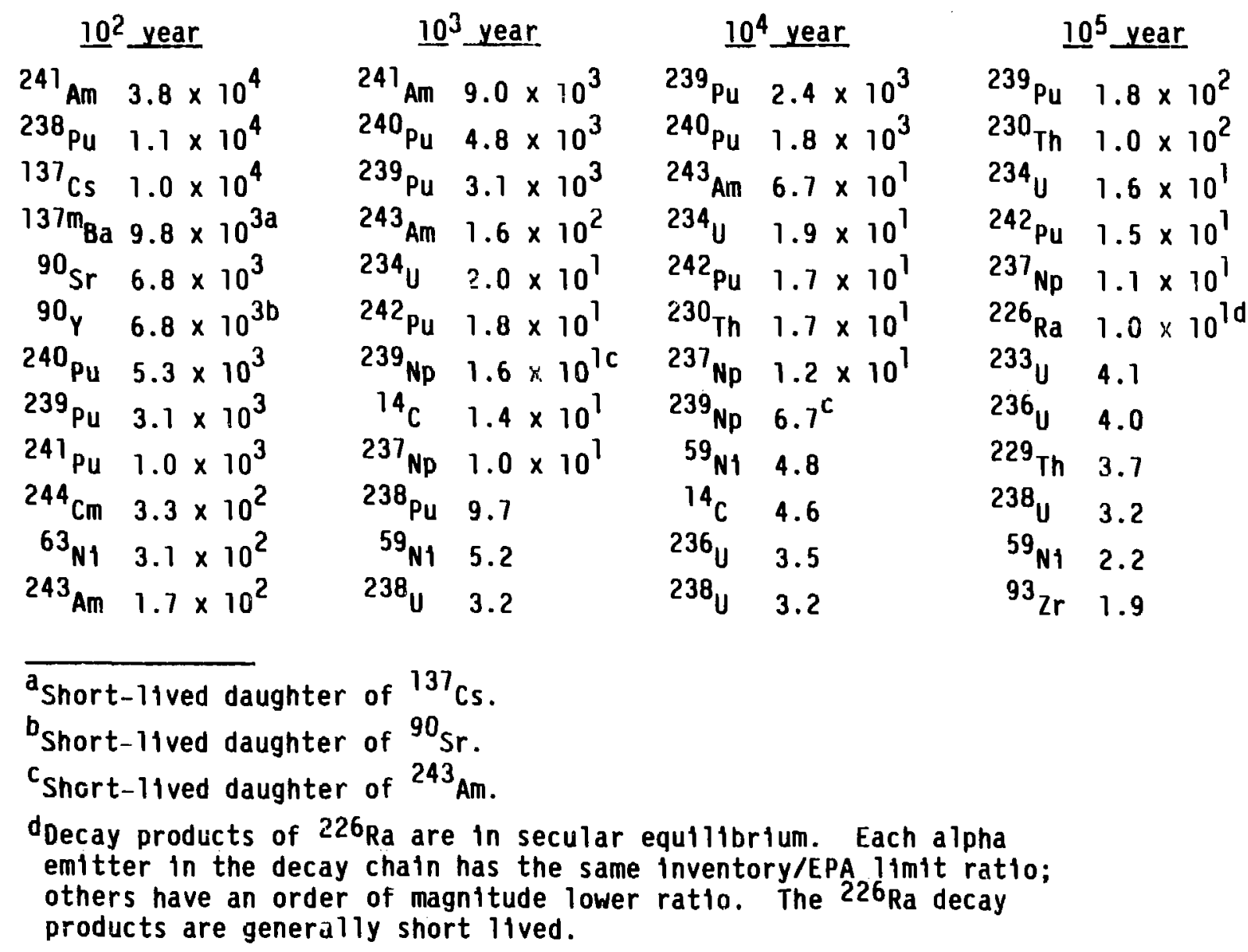

The model used in this analysis is based on the assumption that dissolution rates are 1 imited by diffusion of waste elements into water moving past the solid waste or by bulk-waste dissolution, whichever rate is lower. 6 Waste elements with large solubllities or that are present in very small quantities will dissolve at the bulk-waste dissolution rate; elements with low solubilities will dissolve more slowly. The bulk-waste fractional dissolution rate used in these calculations was $1 \times 10^{-4} / \mathrm{yr}$ except for Cs, Sr, C, and I in spent fuel, where $1 \times 10^{-3} / y r$ was used to account for migration of these 
TABLE VII

RAOIONUCLIOES ORDERED BY RATIO OF

INVENTORY TO EPA LIMIT TOR

PWR HIGH-LEVEL WASTE

Radionuclide and (Inventory/EPA Limit) for Various Decay T1mes

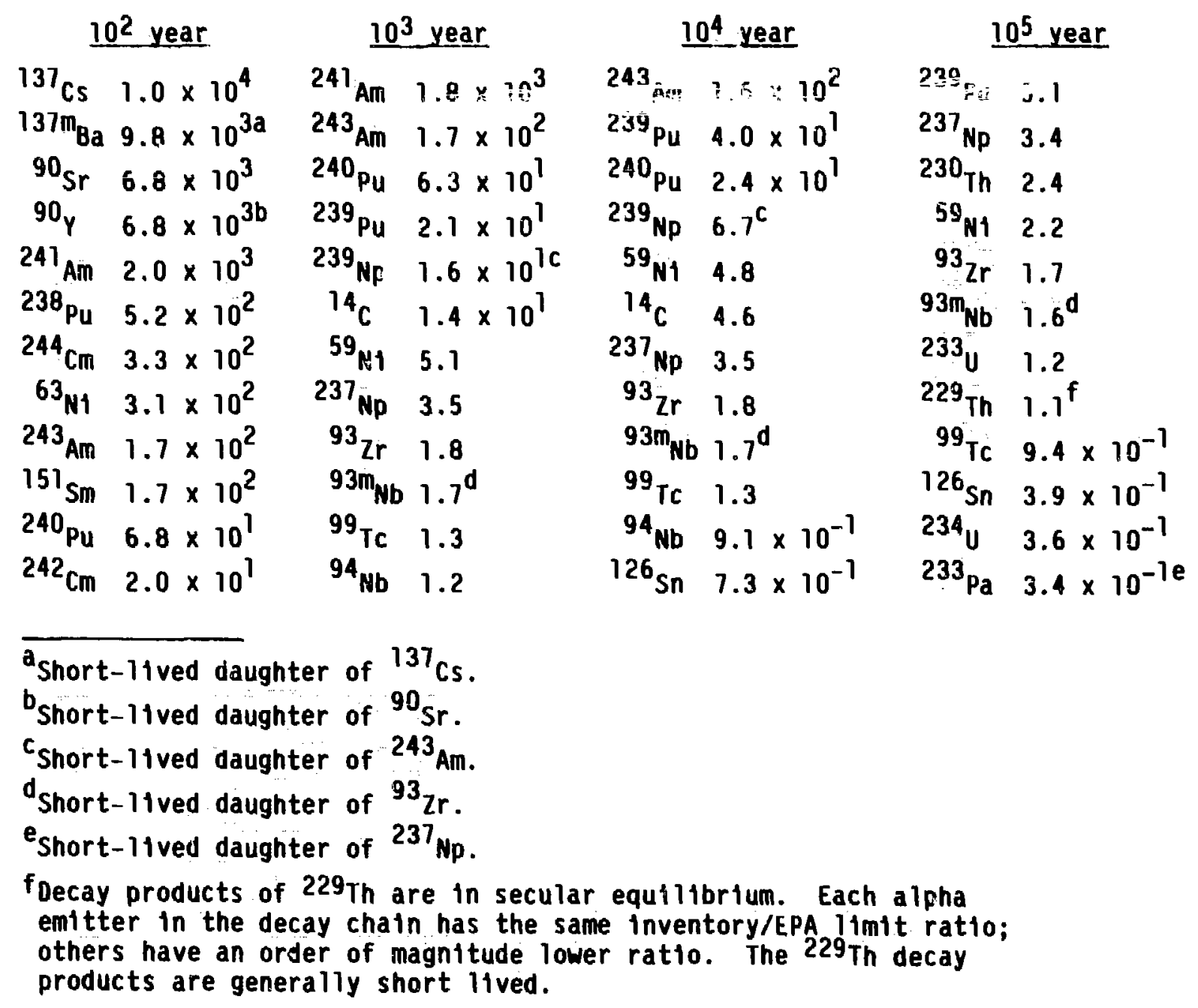




\section{TAELE VIII}

\section{RADIONUCLIDES ORDERED BY RATIO OF \\ INVENTOKY TO EPA LIMLT FOR \\ DEFENSE HIGH-LEVEL WASTE}

Radionuclide and (Inventory/EPA Limit) for Various Decay Times

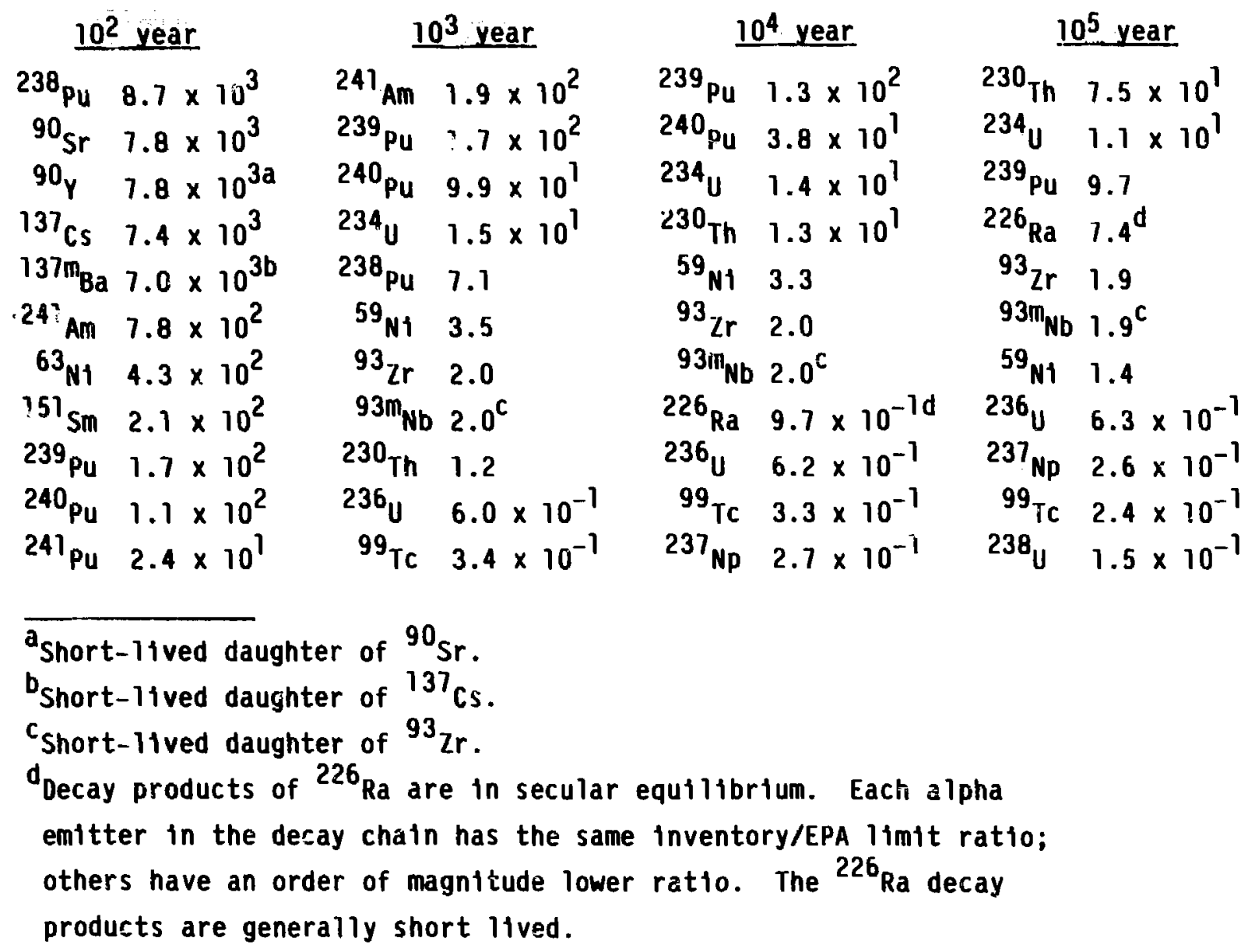

radionuclides to regions of greater access during irradiation. This may be higher than dissolution rates that are ultimately achieved. If lower bulkwaste dissolution rates can be achieved for long times, dissolution rates would be lower than calculated here and solubility would be less important. The model does not account for effects of engineered barriers; in this respect, the model is also very conservative. Estimates of waste-element solubilities and a number of parameters that characterlze the solid waste and water flow 
near the repository are required for the calculation. Table IX 1ists the solubilities assumed for 16 waste elements in water from Yucca Mountain. These elements were chosen for further analysis because their isotopes are prominent in Tables VI to VIII. Some of the solubilities were calculated, 7 some measured, and others were estimated. The solubli1tles 11sted as large are assumed to oe large enough that bulk-waste dissolution and not solubllity would limit dissolution rates under any conditions. 6 The solublitites of carbon and lodine are listed as large for PWR spent fuel but are lower for PWR hlghlevel waste. This varlable solubility reflects an uncertalnty about the physical form and release mechanisms of these elements from spent fuel compared with their separation and storage as calcium or barium carbonate and barium lodate for PWR high-level waste. 4 The other parameters characterizing dissolution are the same as described in Ref. 6 for PWR waste, except that the latest estimate of the maximum recharge rate at Yucca Mountain, $1 \mathrm{~mm} /$ year, was used. 9 Solid waste sizes for defense high-level waste were taken from Ref. 2.

Tables $X, X I$, and $X I I$ list radionuclides ordered by the ratio of dissolution rate to E.PA 1 imit and values of this ratio for PWR spent fuel, PWR highlevel waste, and defense high-level waste, respectively. Several short-lived decay products of radionuclides listed in these tables have not been included because they would not exist long enough to provide solubility controls on dissolution (see table footnotes). If the activity of these radionuclides were counted with their parent radionuclides, the dissolution rate/EPA $11 \mathrm{mit}$ ratio of the parents would increase. How much increase would depend on the number of decay products and their EPA 11mits. As noted above, radionuclides near the top of the 11 st are being released from the solld waste relative to their EPA 1 imits at a faster rate than radionuclides farther down the 11 st. Solubility is not an effective retardation mechanism for elements near the top of the 11st. In particular, radionucildes of neptunium, carbon, technetium, cesium, strontium, radium, and nickel have generaliy moved up in Tables $x$ to xII relative to their positions in the tables ordered by inventory/EPA $11 \mathrm{mit}$ ratios (Tables VI to VIII). Radionuclides of thorium, $t i n$, and zirconium have moved down in Tables $X$ to XII; these elements have solubilities low enough to significantiy limit their dissolution rates. 


\begin{tabular}{|c|c|c|c|}
\hline Element & PWR Spent Fuel & PWR H1gh-Level Waste & $\begin{array}{c}\text { Defense } \\
\text { H1gh-Level Waste }\end{array}$ \\
\hline Np & $1 \times 10^{-3}$ & $1 \times 10^{-3}$ & $1 \times 10^{-3}$ \\
\hline$u$ & $4 \times 10^{-3}$ & $4 \times 10^{-3}$ & $4 \times 10^{-3}$ \\
\hline Pu & $1 \times 10^{-5}$ & $i \times 10^{-5}$ & $1 \times 10^{-5}$ \\
\hline Am & $1 \times 10^{-6}$ & $1 \times 10^{-6}$ & $1 \times 10^{-6}$ \\
\hline $\mathrm{cm}$ & $1 \times 10^{-5}$ & $1 \times 10^{-6}$ & $1 \times 10^{-6}$ \\
\hline Th & $1 \times 10^{-9}$ & $1 \times 10^{-9}$ & $1 \times 10^{-9}$ \\
\hline Ra & $3 \times 10^{-7}$ & $3 \times 10^{-7}$ & $3 \times 10^{-7}$ \\
\hline Cs & large & large & large \\
\hline $\mathrm{Sr}$ & $8 \times 10^{-4}$ & $8 \times 10^{-4}$ & $8 \times 10^{-4}$ \\
\hline Tc & large & large & large \\
\hline c & large & $4 \times 10^{-4}$ & not present \\
\hline I & large & $2 \times 10^{-3}$ & large \\
\hline Sn & $1 \times 10^{-9}$ & $1 \times 10^{-9}$ & $1 \times 10^{-9}$ \\
\hline N1 & $1 \times 10^{-2}$ & $1 \times 10^{-2}$ & $1 \times 10^{-2}$ \\
\hline $2 r$ & $1 \times 10^{-10}$ & $1 \times 10^{-10}$ & $1 \times 10^{-10}$ \\
\hline Sm & $2 \times 10^{-9}$ & $2 \times 10^{-9}$ & $2 \times 10^{-9}$ \\
\hline
\end{tabular}

In addition to the standards imposed by the EPA, the Nuclear Regulatory Commission (NRC) has developed technical criteria for geologic repositories. 10 One criterion limits the release rate of radionuclides from the engineered barrier system to one part in $10^{5}$ per year of the inventory of that radionucilde present at 1000 years following permanent closure of the repository. This release limit joes not apply to radionuclides rsleased at less than one part in $10^{8}$ per year of the total inventory at 1000 years (about $1.7 \times 10^{-5}$ (1/RTHM year). If dissolution from the solid waste as calculated by the dissolution model described above is assumed to be the only mechanism limiting the release rate of radionuclides from the engineered barrier, the dissolution rates can be used to determine which radionuclides do not meet 


\section{TABLE $X$}

RADJONUCLIDES ORUERED BY RATIO OF

DISSISLUTION RATE TO EPA LIMIT FOR PHR

SPENT FUEL a

Radionuclide and Dissolution Räte/EPA Limit $(y r)^{-1}$ for Various Decay Times

$10^{2}$ year

${ }^{137} \mathrm{Cs} \quad 1.0 \times 10^{1}$

${ }^{90} \mathrm{Sr}$

$8.7 \times 10^{-1}$

$3.3 \times 10^{-2}$

${ }^{14} \mathrm{C} 1.5 \times 10^{-2}$

${ }^{63} \mathrm{Ni} 1.0 \times 10^{-2}$

${ }^{241} \mathrm{Am} 5.4 \times 10^{-3}$

${ }^{238} \mathrm{Pu}$

$2.3 \times 10^{-3}$

$242 \mathrm{~cm} 2.0 \times 10^{-3}$

${ }^{243} \mathrm{Cm} \quad 1.3 \times 10^{-3}$

$240 \mathrm{Pu} \quad 1.1 \times 10^{-3}$

$239 \mathrm{Pu}$
$10^{3}$ year

${ }^{14} \mathrm{C} \quad 1.4 \times 10^{-2}$

${ }^{241} \mathrm{Am} \quad 4.5 \times 10^{-3}$

$240 \mathrm{Pu} \quad 1.1 \times 10^{-3}$

$237 \mathrm{~Np} 1.0 \times 10^{-3}$

$239 \mathrm{Pu}$

$6.9 \times 10^{-4}$

${ }^{135} \mathrm{Cs}$

${ }^{129}$ I

59 N1

$3.5 \times 10^{-4}$

$3.1 \times 10^{-4}$

$1.7 \times 10^{-4}$

${ }^{99} \mathrm{Tc} \quad 1.3 \times 10^{-4}$

${ }^{243} \mathrm{Am} 7.8 \times 10^{-5}$

${ }^{242} \mathrm{~cm} 3.2 \times 10^{-5}$
$10^{4}$ year

${ }^{14} \mathrm{C}$

$4.6 \times 10^{-3}$

$237_{\mathrm{Np}} 1.2 \times 10^{-3}$

${ }^{239} \mathrm{Pu} 7.9 \times 10^{-4}$

$240 \mathrm{Pu}$

${ }^{135} \mathrm{Cs}$

$6.1 \times 10^{-4}$

$243 \mathrm{Am}$

$3.4 \times 10^{-4}$

${ }^{129} \mathrm{I}$

$3.4 \times 10^{-4}$

$59 \mathrm{N1} 1.6 \times 10^{-4}$

$226 \mathrm{Ra} 1.5 \times 10^{-4}$

${ }^{99} \mathrm{Tc} 1.3 \times 10^{-4}$

${ }^{234} \mathrm{U} \quad 1.4 \times 10^{-5}$
$10^{5}$ year

${ }^{237}$ Np $1.1 \times 10^{-3}$ ${ }^{226} \mathrm{Ra} 4.7 \times 10^{-4}$ ${ }^{239} \mathrm{Pu} \quad 4.5 \times 10^{-4}$ ${ }^{135}$ Cs $3.4 \times 10^{-4}$ ${ }^{129} \mathrm{I} \quad 3.1 \times 10^{-4}$ ${ }^{99}$ TC $9.4 \times 10^{-5}$ ${ }^{59}{ }_{N 1 .} 7.3 \times 10^{-5}$ ${ }^{242} \mathrm{Pu} 3.7 \times 10^{-5}$ $234 \mathrm{U}$ $1.1 \times 10^{-5}$ $233^{\mathrm{u}}$ $2.9 \times 10^{-6}$ $236_{v}$

$2.8 \times 10^{-6}$

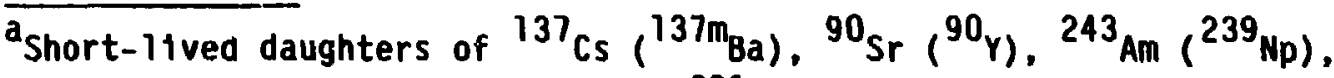
and short-lived decay products of ${ }^{226} \mathrm{Ra}$ have not been included.

this ARC technical criterion. Table XIII lists radionuclides that do not meet the NRC release criterion for the three types of waste at 1000, 10000, and 100000 years after discharge from the reactor based on this calculation. The radionuclides on this list are generally the same as those that head the lists in Tables $X, X I$, and $X I I$; that is, they are 1sotopes of elements whose release is not being limited by solubility. This is a very conservative calculation because it ignores the features of the engineered barrier system except wasteelement solubility and solid-waste dissolution. It does highlight those radionuclides that may require low solid-waste dissolution rates or an engineered barrier systen to meet this NRC criterion. 


\section{TABLE XI}

RADIONUCLIOES ORDERED BY RATIO OF

DISSOLUTION RATE TO EPA LIMIT FOR PWR

HIGH-LEVEL WASTEa

Radionuclide and Dissolution Rate/EPA Limit $(y r)^{-1}$ for Varlous Decay Times

$10^{2}$ year

${ }^{137} \mathrm{Cs} \quad 1.0$

${ }^{90} \mathrm{Sr} 6.7 \times 10^{-1}$

${ }^{244} \mathrm{Cm} \quad 3.3 \times 10^{-2}$

${ }^{238} \mathrm{Pu} \quad 1.1 \times 10^{-2}$

$63_{\mathrm{N1}}$

$2 ! 2 \mathrm{~cm}$

$8.1 \times 10^{-3}$

$2.0 \times 10^{-3}$

${ }^{241} \mathrm{Am} 1.7 \times 10^{-3}$

$240 \mathrm{Pu} \quad 1.4 \times 10^{-3}$

${ }^{243} \mathrm{Cm} 1.3 \times 10^{-3}$

$239 \mathrm{Pu}$

$23{ }^{\mathrm{Np}}$

$3.5 \times 10^{-4}$

$3.2 \times 10^{-4}$
$10^{3}$ yeai

${ }^{240} \mathrm{Pu} \quad 1.3 \times 10^{-3}$

${ }^{241} \mathrm{Am}$

$239 \mathrm{Pu}$

${ }^{237} \mathrm{~Np} 3.5 \times 10^{-4}$

$243 \mathrm{Am} 2.3 \times 10^{-4}$

${ }^{14} \mathrm{C}$

59 N

${ }^{99} \mathrm{Tc}$

$234 \mathrm{U}$

$135 \mathrm{Cs}$

$242 \mathrm{~cm}$

$10^{4}$ year

$10^{5}$ year

$6.2 \times 10^{-4}$

$4.3 \times 10^{-4}$

$2.7 \times 10^{-4}$

$1.3 \times 10^{-4}$

$1.3 \times 10^{-4}$

$4.7 \times 10^{-5}$

$3.5 \times 10^{-5}$
${ }^{239} \mathrm{Pu}$

$240 \mathrm{Pu}$

$237 \mathrm{~Np}$

243 Am

${ }^{99} \mathrm{~T}$

59

${ }^{14} \mathrm{C}$

$234 \mathrm{U}$

${ }^{135} \mathrm{Cs}$

${ }^{129}$ I

$233_{\mathrm{u}}$
$6.8 \times 10^{-4}$

$4.1 \times 10^{-4}$

$3.5 \times 10^{-4}$

$2.6 \times 10^{-4}$

$1.3 \times 10^{-4}$

$1.2 \times 10^{-4}$

$7.3 \times 10^{-5}$

$4.6 \times 10^{-5}$

$3.4 \times 10^{-5}$

$3.1 \times 10^{-5}$

$3.2 \times 10^{-5}$

$1.5 \times 10^{-5}$
${ }^{239} \mathrm{Pu}$

$5.1 \times 10^{-4}$

$237 \mathrm{~Np}$

$3.4 \times 10^{-4}$ $233 \mathrm{U}$

$1.2 \times 10^{-4}$

${ }^{39} \mathrm{TC} 9.4 \times 10^{-5}$

$59^{N 1} 5.7 \times 10^{-5}$

$234_{U}$

$3.6 \times 10^{-5}$

${ }^{135} \mathrm{Cs}$

$3.3 \times 10^{-5}$

129

$3.1 \times 10^{-5}$

$226_{\mathrm{Ra}}$

$2.4 \times 10^{-5}$

${ }^{242} \mathrm{Pu}$

$7.9 \times 10^{-6}$

${ }^{236} \mathrm{U}$

$3.2 \times 10^{-6}$

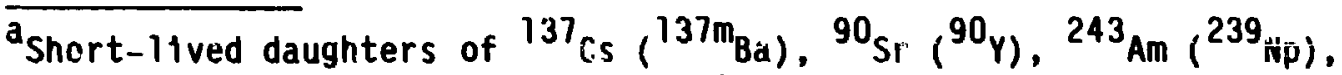
and sirort-lived decay products of ${ }^{226} \mathrm{Ra}$ have not been included.

\section{EFFECTS OF SORPTION}

Section IV has outlined how solubility can influence dissolution rates of radionuclides from solid waste. These dissolition rates provide a source term for transport of radionuclides in water passing through the repository and moving toward the environment. Sorption will affect ine rate at which radionuclides move with the water. Radionuclides that are strongly sorbed will move more slowly than the average water velocity; radionuclides that are not sorbed may move at about the same velocity as the water. During transport, radionuclides will decay. If the time required to transport a radionuclide from the repository to the environment is much longer than the half-life of the radionuclide, release to the environment will be low. Based on this simplified discussion, a measure of the effect of sorption would be the fraction of a 


\section{RADIONUCLIDES ORDERED BY RATIO OF DISSOLUTION RATE TO EPA LIMIT FOR DEFENSE HIGH-LEVEL WASTE ${ }^{2}$.}

Radionucilde and Bissolution Rate/EPA Limit (yr)-1 for Various Decay Times

\section{$10^{2}$ year}

${ }^{90} \mathrm{Sr} \quad 7.6 \times 10^{-1}$

${ }^{137}$ Cs $7.4 \times 10^{-1}$

${ }^{238} \mathrm{Pu} \quad 2.3 \times 10^{-1}$

241 Am $3.5 \times 10^{-2}$

${ }^{63} \mathrm{N1} 2.1 \times 10^{-2}$

${ }^{239} \mathrm{Pu} \quad 4.6 \times 10^{-3}$

$240 \mathrm{Pu}$

$2.9 \times 10^{-3}$

$234 \mathrm{U}$

$9.9 \times 10^{-4}$

$241 \mathrm{Pu} \quad 6.4 \times 10^{-4}$

${ }^{59} \mathrm{N1} 3.6 \times 10^{-4}$

$236_{\mathrm{U}}$

$5.0 \times 10^{-5}$

\section{$10^{3}$ year}

$241_{\text {Anr }} 1.9 \times 10^{-2}$

$239 \mathrm{Pu} \quad 5.4 \times 10^{-3}$

$240 \mathrm{Pu}$

$3.2 \times 10^{-3}$

$234 \mathrm{U}$

$1.2 \times 10^{-3}$

59 N1 $3.5 \times 10^{-4}$

${ }^{238} \mathrm{Pu}$

$2.3 \times 10^{-4}$

$236 \mathrm{U}$

$5.1 \times 10^{-5}$

${ }^{99} \mathrm{TC} \quad 3.4 \times 10^{-5}$

$63 \mathrm{N1} 3.2 \times 10^{-5}$

$237_{\mathrm{Np}}$

${ }^{135} \mathrm{Cs}$

$2.7 \times 10^{-5}$

$1.5 \times 10^{-5}$
$10^{4}$ year

${ }^{239} \mathrm{Pu}$

$240 \mathrm{Pu}$

$5.7 \times 10^{-3}$

$1.7 \times 10^{-3}$

$234_{\mathrm{U}}$

$1.2 \times 10^{-3}$

${ }^{59} \mathrm{N1} 3.3 \times 10^{-4}$

226 Rá

$9.7 \times 10^{-5}$

$235_{\mathrm{U}}$

$5.2 \times 10^{-5}$

${ }^{99} \mathrm{TC} 3.3 \times 10^{-5}$

237

$2.7 \times 10^{-5}$

${ }^{135} \mathrm{Cs}$

$1.5 \times 10^{-5}$

$238_{\mathrm{U}}$

$1.3 \times 10^{-5}$

${ }^{242} \mathrm{Pu}$

$6.6 \times 10^{-6}$

105 year

${ }^{239} \mathrm{Pu}$

$9.7 \times 10^{-4}$

$234_{\mathrm{U}}$

$9.5 \times 10^{-4}$

${ }^{226}$ Ra $7.4 \times 10^{-4}$

${ }^{59}{ }^{N 1} .1 .4 \times 10^{-4}$

${ }^{236} \mathrm{U} \quad 5.3 \times 10^{-5}$

237 Np $2.6 \times 10^{-5}$

${ }^{99} \mathrm{Tc} 2.4 \times 10^{-5}$

${ }^{135}$ Cs $1.5 \times 10^{-5}$

$238_{U} \quad 1.3 \times 10^{-5}$

$242 \mathrm{Pu} \quad 1.3 \times 10^{-5}$

$233 \mathrm{U}$

$7.9 \times 10^{-6}$

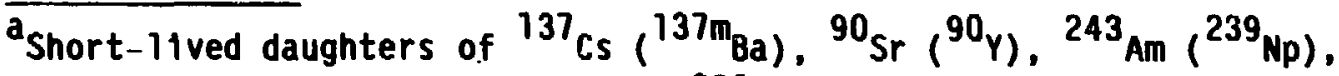
and short-lived decay piroducts of ${ }^{226} \mathrm{Ra}$ have not been included.

radionuclide originally released to the water that is finaliy released the environment.

Transport and sorption are very complex processes that depend on detalls of the hydrology, water chemistry, and mineralogy along transport paths. For this analysis, which is aimed only at assessing the relative importance of various radionuclides for site characterization, a much simpler model was used. It was assumed that water transport from the repositcry to the environment could be characterized by a travel time $\left(t_{w}\right)$ and that each element could be assigned a retardation factor $\left(R_{f}\right)$ that defines the ratio of water velocity to waste-element transport velocity. ${ }^{11}$ From these two parameters, the element travel time from the repository to the environment is $\left(R_{f} t_{w}\right)$. The fraction of that radionuclide left from simple decay (with half-11fe $t_{h}$ ) 


\section{TABLE XIII}

RADLONUCLIDES NOT MEETING THE

NRC TECHNICAL CRITERION ON

RELEASE IF ONLY DISSOLUTION LIMITS RELEASEa

Radionuclide Identity at Varlous Decay Times

Spent fuel

$\frac{10^{3} \text { year }}{{ }^{14} \mathrm{C}}$
${ }^{237} \mathrm{~Np}$
${ }^{59} \mathrm{N1}$
${ }^{99} \mathrm{TC}$
${ }^{135} \mathrm{CS}$
${ }^{129} \mathrm{I}$

\begin{tabular}{|c|c|}
\hline $10^{4}$ year & $10^{5}$ year \\
\hline${ }^{14} \mathrm{C}$ & ${ }^{237} \mathrm{~Np}$ \\
\hline 237 Np & ${ }^{59} \mathrm{Ni}$ \\
\hline${ }^{59}{ }_{\mathrm{Ni}}$ & ${ }^{99} \mathrm{TC}$ \\
\hline${ }^{99} \mathrm{TC}$ & ${ }^{135} \mathrm{cs}$ \\
\hline${ }^{135} \mathrm{Cs}$ & ${ }^{226} \mathrm{Ra}$ \\
\hline $129_{I}$ & ${ }^{129} \mathrm{I}$ \\
\hline
\end{tabular}

High-level waste

$$
\begin{aligned}
& { }^{14} \mathrm{C} \\
& { }^{237} \mathrm{~Np} \\
& { }^{59} \mathrm{N1} \\
& { }^{99} \mathrm{TC} \\
& { }^{135} \mathrm{Cs} \\
& { }^{240} \mathrm{Pu} \\
& { }^{239} \mathrm{Pu}
\end{aligned}
$$

$\begin{array}{rr}{ }^{237} \mathrm{~Np} & { }^{237}{ }_{\mathrm{Np}} \\ { }^{59}{ }_{\mathrm{N1}} & { }^{59} \mathrm{N1} \\ { }^{99} \mathrm{Tc} & { }^{99} \mathrm{TC} \\ { }^{135} \mathrm{Cs} & { }^{135} \mathrm{Cs} \\ { }^{240} \mathrm{Pu} & 2399_{\mathrm{Pu}}\end{array}$

Defense high-level waste

$$
\begin{aligned}
& { }^{59} \mathrm{N1} \\
& { }^{63}{ }_{\mathrm{N} 1} \\
& { }^{99} \mathrm{TC} \\
& { }^{234} \mathrm{U} \\
& { }^{241} \mathrm{Am} \\
& { }^{239} \mathrm{Pu} \\
& { }^{240} \mathrm{Pu} \\
& { }^{238} \mathrm{Pu}
\end{aligned}
$$

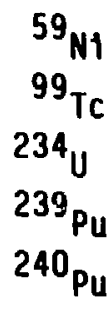

$$
\begin{aligned}
& { }^{59} \mathrm{N1} \\
& { }^{99} \mathrm{TC} \\
& { }^{234} \mathrm{U} \\
& { }^{226} \mathrm{Ra}
\end{aligned}
$$

adssolution rates greater than one part in $10^{5}$ per year of the 1000-year inventory of that radionuclide and dissolution rates greater than $1.7 \times 10^{-5}$ C1/MTHM year. 
after a time $(t)$ is $\exp \left(-0.693 t / t_{h}\right)$ (Ref. 12). Thus, for the time required to transport the radionuclide from the repository to the environment, the fraction remaining would be

$$
f=\exp \left(-0.693 R_{f} t_{w} / t_{h}\right)
$$

The effect of sorption can be combined with the effect of solubility by defining the quantity

$$
\left.R_{e}=\text { (dissolution rate/EPA } 1 \text { imit }\right) \exp \left(-0.693 R_{f} t_{w} / t_{h}\right) \text {, }
$$

where the (dissolution rate/EPA limit) ratios have been 1isted previousiy in Tables $X$ to XIL. The quantity $R_{e}$ is a measure of the release rate of a radionucilde to the environment relative to its EPA release limit, where the geochemical processes of solubility and sorption are the only retardation mechanisms considered. This release would start at a time $\left(R_{r} t_{w}\right)$ after waste dissolution starts.

Equation (1), which assesses the effects of sorption on radionuclide transport, is only an approximation. Its main defictency is that it is based on simple radioactive decay. This assumption is generally adequate for activation products, fission products, and many actinides. However, several actinides that are part of long-lived decay chains can be produced along the transport path as precursors decay. A primary example is ${ }^{226} \mathrm{Ra}$, a decay product of ${ }^{230} \mathrm{Th}$. These calculations also ignore the effects of dispersion during transport. Although such a simple model is inadequate for actual transport calculations, it is acceptable for the assessment being done here.

Retardation factors for most of the waste elements examined here were chosen from a compliation of sorption data measured on tuffs from Yucca Mountain. ${ }^{11}$ Table XIV lists the values used. The measurements have been done on a variety of tuffs and retardation factors can vary significantiy with the type of mineral present in the tuff. ${ }^{11}$ The retardation factors used in this analysis are generally near the average or median of the measurements. Varlations of an order of magnitude or more are possible. Data for carbon (as carbonate), nicke1, zirconlum, and samarlum were estimated. Water travel times from the repository to the environment have not yet been determined for Yucca 
TABLE XIV

WASTE-ELEMENT RETARDATION FACTORS

\begin{tabular}{cr} 
Element & \multicolumn{2}{c}{ Retardation } \\
\cline { 2 - 3 } $\mathrm{Np}$ & 50 \\
$U$ & 25 \\
$\mathrm{Pu}$ & 500 \\
$\mathrm{Am}$ & 1000 \\
$\mathrm{Cm}$ & 100 \\
$\mathrm{Th}$ & 500 \\
$\mathrm{Ra}$ & 1000 \\
$\mathrm{CS}$ & 1000 \\
$\mathrm{Sr}$ & 700 \\
$\mathrm{TC}$ & 1 \\
$\mathrm{C}$ & 1 \\
$\mathrm{I}$ & 1 \\
Sn & 1000 \\
$\mathrm{N1}$ & 20 \\
$\mathrm{Zr}$ & 100 \\
$\mathrm{Sm}$ & 1000
\end{tabular}

aRetardation factor is the ratio of water velocity to waste-element velocity; see Ref. 11 .

Mountain. Preliminary estimates that are consistent with $1 \mathrm{~mm} / \mathrm{year}$ recharge are in the range of 20000 years or greater. 9 Water travel times that are greater than 1000 years are acceptable under the NRC's technical criteria. ${ }^{10}$ Radionuclide travel time and $R_{e}$ were calculated for water travel times of 1000 and 20000 years to assess the effect of this parameter on the 1dentity of the radionuclides released to the environment in significant quantities relative to their EPA release $11 \mathrm{mits}$.

Tables XV, XVI, and XVII list radionuclides ordered by the ir travel time and initial value of $R_{e}$ as defined in Eq. (2) for PWR spent fuel, PWR highlevel waste, and defense high-level waste, respectively. Radionuclides that are near tise top of the 11sts have shorter travel times because they are not sorbed well, and solubility is not limiting their concentrations. Because of the exponential term in Eq. (2), radionuclides with short half-lives compared with the water travel time decay before release no matter how well they are sorbed. Radionuclides with longer half-lives decay if their half-lives are short compared with the product $R_{f} t_{w}$; thus, their decay depends on retardation by sorption. Other waste elements have long-11ved 1sotopes that are 
TABLE XV

RAOIONUCLIOES ORDERED BY TRAVEL TIME

AND INITIAL RELEASE RATE ( $\left.R_{e}\right)$ FOR

PWR SPENT FUEL

Water Travel Time $=1000$ year

\section{Radionuclide Irtis}

Radionuclide

${ }^{14} \mathrm{C}$

${ }^{129} 1$

${ }^{99} \mathrm{TC}$

${ }^{59}{ }_{\mathrm{N1}}$

$234 \mathrm{U}$

$238_{\mathrm{U}}$

$236_{\mathrm{U}}$

$235 \mathrm{U}$

$233_{\mathrm{U}}$

$237_{\mathrm{Np}}$

${ }^{93} \mathrm{Zr}$

$242 \mathrm{Pu}$

${ }^{230} \mathrm{Th}$

${ }^{239} \mathrm{Pu}$

${ }^{135} \mathrm{Cs}$

${ }^{126}$ Sn
Travel Tlme

\section{Travel Time}

(y)

$R_{e}$
$(y r)^{-1}$

$1.4 \times 10^{-2}$

$3.2 \times 10^{-4}$

$1.3 \times 10^{-4}$

$1.4 \times 10^{-4}$

$1.0 \times 10^{-5}$

$2.2 \times 10^{-6}$

$1.8 \times 10^{-6}$

$1.2 \times 10^{-7}$

$1.1 \times 10^{-9}$

$4.1 \times 10^{-4}$

$5.2 \times 10^{-14}$

$1.5 \times 10^{-6}$

$3.1 \times 10^{-9}$

$3.8 \times 10^{-10}$

$2.7 \times 10^{-4}$

$7.1 \times 10^{-13}$
Water Travel Time $=20000$ year

\begin{tabular}{ccc} 
Radionucl1de & $\begin{array}{c}\text { Radtonuclide } \\
\text { Trave1 Time } \\
\text { (vear) }\end{array}$ & $\begin{array}{c}\text { Inttial } \\
R_{e} \\
(y r)^{-1}\end{array}$ \\
\cline { 1 - 2 }${ }^{14} \mathrm{C}$ & $2 \times 10^{4}$ & $1.4 \times 10^{-3}$ \\
${ }^{129} \mathrm{I}$ & $2 \times 10^{4}$ & $3.2 \times 10^{-4}$ \\
${ }^{99} \mathrm{Tc}$ & $2 \times 10^{4}$ & $1.2 \times 10^{-4}$ \\
${ }^{59} \mathrm{Ni}$ & $4 \times 10^{5}$ & $4.3 \times 10^{-6}$ \\
${ }^{234} \mathrm{U}$ & $5 \times 10^{5}$ & $2.7 \times 10^{-6}$ \\
${ }^{238_{\mathrm{U}}}$ & $5 \times 10^{5}$ & $2.2 \times 10^{-6}$ \\
${ }^{236} \mathrm{U}$ & $5 \times 10^{5}$ & $1.8 \times 10^{-6}$ \\
${ }^{235} \mathrm{U}$ & $5 \times 10^{5}$ & $1.2 \times 10^{-7}$ \\
${ }^{233} \mathrm{U}$ & $5 \times 10^{5}$ & $1.3 \times 10^{-10}$ \\
${ }^{237} \mathrm{~Np}$ & $1 \times 10^{6}$ & $3.0 \times 10^{-4}$ \\
${ }^{93} \mathrm{Zr}$ & $2 \times 10^{6}$ & $2.2 \times 10^{-14}$ \\
${ }^{242} \mathrm{Pu}$ & $1 \times 10^{7}$ & $3.7 \times 10^{-14}$ \\
${ }^{135} \mathrm{Cs}$ & $2 \times 10^{7}$ & $3.1 \times 10^{-6}$ \\
& &
\end{tabular}

not strongly sorbed but do have low solubilities; zirconium is one example.

The same radionuclides head the lists for ali three types of fuel; an exception exists for defense $h$ igh-level waste where ${ }^{14} \mathrm{C}$ and ${ }^{129} \mathrm{I}$ are not present in significant amounts. The same radionuclides are also present for water travel times of 1000 and 20000 years; with the longer water travel time, the radionuclide travel time is longer and the values of $R_{e}$ are smaller.

VI. EFFECTS OF PHYSICAL AND CHEMICAL FORMS OF THE WASTE

As noted earlier, considerable uncertainty still exists about the type of waste to be stored in the proposed repositories. For many waste elements, the 


\section{TABLE XVI}

RADIONUCLIDES ORDERED BY TRAVEL TIME

AND INITLAL RELEASE RATE ( $\left.R_{e}\right)$ FOR

PWR HIGH-LEVEL WASTE.

Water Travel T1me $=1000$ year

\begin{tabular}{|c|c|c|}
\hline Radionuclide & $\begin{array}{l}\text { Radionuclide } \\
\text { Travel T1me } \\
\text { (year) } \\
\end{array}$ & $\begin{array}{c}\text { Inttial } \\
R_{e} \\
(y r)^{-1} \\
\end{array}$ \\
\hline${ }^{14} \mathrm{C}$ & $1 \times 10^{3}$ & $2.1 \times 10^{-4}$ \\
\hline${ }^{99} \mathrm{TC}$ & $1 \times 10^{3}$ & $1.3 \times 10^{-4}$ \\
\hline 129 & $1 \times 10^{3}$ & $3.2 \times 10^{-5}$ \\
\hline${ }^{59}{ }_{\mathrm{N} 1}$ & $2 \times 10^{4}$ & $1.1 \times 10^{-4}$ \\
\hline $234 u$ & $2.5 \times 10^{4}$ & $2.6 \times 10^{-5}$ \\
\hline $238_{\mathrm{U}}$ & $2.5 \times 10^{4}$ & $1.6 \times 10^{-6}$ \\
\hline $236 u$ & $2.5 \times 10^{4}$ & $1.3 \times 10^{-6}$ \\
\hline${ }^{233} \mathrm{U}$ & $2.5 \times 10^{4}$ & $1.2 \times 10^{-7}$ \\
\hline${ }^{235} \mathrm{U}$ & $2.5 \times 10^{4}$ & $8.6 \times 10^{-8}$ \\
\hline $237 \mathrm{~Np}$ & $5 \times 10^{4}$ & $3.1 \times 10^{-4}$ \\
\hline${ }^{93} \mathrm{Zr}$ & $1 \times 10^{5}$ & $4.0 \times 10^{-14}$ \\
\hline${ }^{242} \mathrm{Pu}$ & $5 \times 10^{5}$ & $7.6 \times 10^{-7}$ \\
\hline & $5 \times 10^{5}$ & $2.5 \times 10^{-9}$ \\
\hline & $5 \times 10^{5}$ & $2.0 \times 10^{-10}$ \\
\hline & $1 \times 10^{6}$ & $2.7 \times 10^{-5}$ \\
\hline & $1 \times 10^{6}$ & $5.5 \times 10^{-13}$ \\
\hline
\end{tabular}

Water Travel Time $=20000$ year

Radtanuc.7ide

Radionuclide

Inttial.

Travel Time

$R_{e}$
$(y r)^{-1}$

${ }^{99} \mathrm{TC}$

129 I

${ }^{14} \mathrm{C}$

${ }^{59} \mathrm{Ni}$

$234 \mathrm{U}$

$238_{U}$

$236_{\mathrm{U}}$

$235 \mathrm{U}$

$233 \mathrm{U}$

$237 \mathrm{~Np}$

${ }^{93} \mathrm{Zr}$

$242 \mathrm{Fu}$

${ }^{135} \mathrm{Cs}$ (year)

$2 \times 10^{4}$

$2 \times 10^{4}$

$2 \times 10^{4}$

$4 \times 10^{5}$

$5 \times 10^{5}$

$5 \times 10^{5}$

$5 \times 10^{5}$

$5 \times 10^{5}$

$5 \times 10^{5}$

$1 \times 10^{6}$

$2 \times 10^{6}$

$1 \times 10^{7}$

$2 \times 10^{7}$
$1.2 \times 10^{-4}$

$3.2 \times 10^{-5}$

$2.1 \times 10^{-5}$

$3.3 \times 10^{-6}$

$6.7 \times 10^{-6}$

$1.6 \times 10^{-6}$

$1.3 \times 10^{-6}$

$8.6 \times 10^{-8}$

$1.6 \times 10^{-8}$

$2.3 \times 10^{-4}$

$1.7 \times 10^{-14}$

$1.9 \times 10^{-14}$

$3.1 \times 10^{-7}$

actual waste form w111 not strongly influence element dissolution rates or how strongly elements are sorbed along flow paths. However, the physical and chemical form of the waste can control release and transport of some radionuclides. This is particularly true of the repository at Yucca Mountain, which is currently proposed for the unsaturated zone, where vapor as well as aqueous transport are possible. Both ${ }^{14} \mathrm{C}$ (as carbon dioxide) and ${ }^{129}{ }_{1}$ could be released from spent fuel as gases. The analysis presented here assumed aqueous transport. Thus, for spent fuel, a separate transport path may be important. If both of these radionuclides are separated during reprocessing and stored as 


\section{TABLE XVII}

RADIONUCLIDES ORDERED BY TRAVEL TIME AND INITIAL RELEASE RATE $\left(R_{e}\right)$ FOR DEFENSE HIGH-LEVEL WASTE

Water Travel Time $=1000$ year

Radionuclide Initial

Radionuclide

\section{Travel Time}

${ }^{99} \mathrm{TC}$

${ }^{59} \mathrm{NI}$

$234_{U}$

$236 \mathrm{U}$

$238_{\mathrm{U}}$

$235 \mathrm{U}$

$233 \mathrm{u}$

$237 \mathrm{~Np}$

${ }^{93} \mathrm{Zr}$

$245 \mathrm{~cm}$

${ }^{246} \mathrm{~cm}$

$247 \mathrm{~cm}$

${ }^{248} \mathrm{Cm}$

$147 \mathrm{Sm}$

$242 \mathrm{Pu}$

${ }^{230} \mathrm{Th}$

${ }^{239} \mathrm{Pu}$

${ }^{135} \mathrm{cs}$

${ }^{126}$ Sn (year)

$1 \times 10^{3}$

$2 \times 10^{4}$

$2.5 \times 10^{4}$

$2.5 \times 10^{4}$

$2.5 \times 10^{4}$

$2.5 \times 10^{4}$

$5 \times 10^{4}$

$1 \times 10^{5}$

$1 \times 10^{5}$

$1 \times 10^{5}$

$1 \times 10^{5}$

$1 \times 10^{5}$

$2 \times 10^{5}$

$5 \times 10^{5}$

$5 \times 10^{5}$

$5 \times 10^{5}$

$1 \times 10^{6}$

$1 \times 10^{6}$
$2.5 \times 10^{4}$
$R_{e}$
$(y r)^{-1}$

$3.4 \times 10^{-5}$

$3.0 \times 10^{-4}$

$9.2 \times 10^{-4}$

$5.0 \times 10^{-5}$

$1.3 \times 10^{-5}$

$2.3 \times 10^{-6}$

$2.9 \times 10^{-8}$

$1.7 \times 10^{-5}$

$2.3 \times 10^{-11}$

$6.9 \times 10^{-12}$

$3.2 \times 10^{-15}$

$1.2 \times 10^{-15}$

$1.0 \times 10^{-15}$

$1.1 \times 10^{-13}$

$1.6 \times 10^{-6}$

$2.1 \times 10^{-8}$

$2.6 \times 10^{-9}$

$1.2 \times 10^{-5}$

$4.8 \times 10^{-12}$
Water Travel Time $=20000$ year

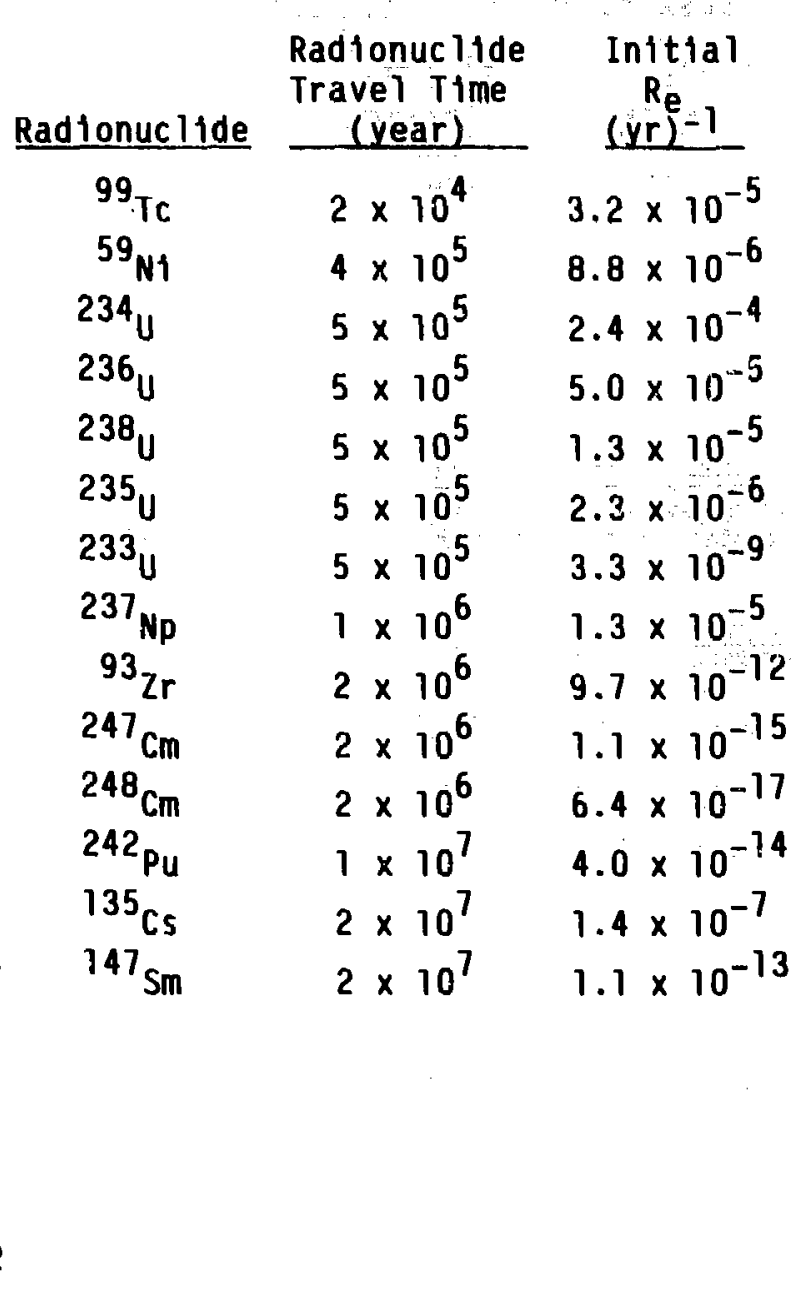

solids, gases probably will not be released. However, ${ }^{14} \mathrm{C}$ as aqueous carbonate could exchange with gaseous carbon dioxide in the unsaturated zone. The entire question of gaseous transport and its relation to aqueous-phase transport remains to be investigated.

A long-lived isotope of nickel, ${ }^{59} \mathrm{Ni}$, is prominent in the tables presented here. For PWR waste, this isotope comes from subassembly structural material in the form of stainless steel. The solubility of nickel was based 
on $\mathrm{NiO}$ and $\mathrm{NiCO}_{3}$, which give similar solubilities in water from Yucca Mountain. This solublitty is relatively high (see Table $[X$ ). If the stainless steel passivates during storage, release rates of nickel from PWR waste may be much lower than calculated here based on nickel solubility. For defense htgh-level waste, nickel is in the borosllicate glass with the other waste elements. The release rates of nickel based on solublitty are probably appropriate in this case.

\section{IHPORTANT RAOIONUCLIDES}

Which rationucildes are most important for a repository at Yucca Mountain? Different answers arise from consideration of different time scales, transport mechanisms, regulations, or waste types. Three aspects of this question are addressed in this report.

1. Which radionuclides are present in waste in large quantities relative to their EPA release limts? These are the radionucildes for which the retardation processes of solublilty and sorption must be most effective. Such radionuclides are important because they must be addressed during performance assessment, and thus, must have the solubility and sorption data base for that analysis.

2. Which radionuclides are not retarded by solubility and sorption and are present in large enough quantities to pose release froblems? This question can be addressed by performance assessment calculations using estimated solubilities and sorption coefficients. A simplified analysis in tis report determined how solubility limits dissolution rates and how sorption limits transport. The results of this analysis highlight radionuclides that may require special consideration because they are not retarded strongly. These radionuclides are important because spectal design considerations or performance assessments may be required to assure their containment.

3. Which radionuclides might require spectal consideration because of the physical or chemical form of the waste? These are radionuclides that may exhibit unique source-term or transport behavior. They are also important because they may require spectal data or assessment techniques for performance-assessment calculations. As solid-waste forms become better defined, other radionuclides may be added to this category. 
The radionuclides present in large quantities relative to their EPA release 11 mits are a function of waste type and storage time. Early in the storage perlod ( 0 to 500 years), two elements with short-lived 1sotopes ( $\mathrm{Sr}$ and Cs) are important (see Tables VI, VII, and VIII). However, the waste package must contaln wastes for at least 300 years $^{10}$ so that uncer expected conditions, these short-lived radionuclides would decay before significant release occurred. Solubility and sorption behavior of these elements for dssessing the short-lived isotope transport would be important if the wastepackage falled early. Solubility and sorption will be important retardation mechanisms over 1000-10 000 years; the same radionuclides are present in large quantities relative to their EPA release limits over that time for the three types of waste considered here (see Tables VI, VII, and VIII). Isotopes of $\mathrm{Am}, \mathrm{Pu}, \mathrm{Th}, \mathrm{Np}$, and $U$ are the most important during that perlod. Isotopes of C, N1, Zr, TC, Ra, and Sn are present in smaller, but stili stgnificant, amounts over the same period. Although current estimates of solubilities for many of these elements may be low (see Table $I X$ ) or estimates of retardation factors may be high (see Table XIV), data used for transport calculations will have to be supported by an extensive data base.

How solubility influences radionuclide dissolution rates is sumarized in Tables $X, X I$, and XII; how sorption influences radionuclide release rates and travel times is summarized in Tables XV, XVI, and XVII. These analyses were based on estimates of waste element solubilities and sorption coefficlents. Three elements with large solubilities and small sorption coefficlents that have significant quantities of some 1sotopes in most types of waste are $C, T C$, and I. Ocher elements with moderately high solubilities and intermediate sorption coefficients are $N 1, N p$, and $U$. These elements have isotopes with the shortest travel times and highest release rates in Tables XV, XVI, and XVII. If water travel times from the repository to the environment are as large as expected (20 000 year or more), the proposed Yucca Mountain site should have 11ttle problem meeting the EPA release standard. 5 However, water travel times shorter than 10000 year could result in release of some of the radionuclides with high solubilities and little or no sorption during the perlod covered by the EPA standard. Some consideration should be given to better containment of these radionuclides.

All considerations of important radionuclides so far have assumed the normal mechanisms of waste dissolution and transport in water passing. through 
the repository. However, some radionuclides may not move in that manner because of the phystcal or chemical form of the waste. Radionuclides that can be released as gases may have a spectal transport path through the unsaturated zone at Yucca Mountain. In particular, ${ }^{14} \mathrm{C}$ and ${ }^{129} \mathrm{I}$ release from spent fuel should be consldered. These radionuclides will be separated from highlevel waste and should not pose the same problem in that case. 4.1so, isotopic exchange between carbonate in the zqueous phase and carbon dloxide in the vapor phase should be examined for its significance. Release of $\mathrm{N} 1$ isotopes from PWR wastes may be much less than estimate: here based on solubility considera. tions if the $\mathrm{NI}$ is stored as stainless steel; however, $\mathrm{N1}$ in defense high-level waste would not be constrained by stainless-steel dissolution.

\section{CONCLUSIONS}

Providing a single list of important radionuclides and the work required to assess their release and transport is a difficult task. Uncertainties as to types of waste, transport pathways, and data needed for transport calculations create several problems of similar importance. Based on the assessment done here, the following recommendations are made for solubility and sorption data needs.

1. Provide a solubility and sorption data base for the elements Am, Pu, Th, Np, and U.

2. Provide a solubility and sorption data base for the elements $\mathrm{Sr}, \mathrm{CS}$, C. N1, Zr, TC, Ra, and Sn.

3. Study how elements with high solubility and low sorpt in $(C, T C$, and I) could be better contained at Yucca Mountain. Recommend experimental work, design changes, or calculations to assure their containment.

4. Study the potential for gaseous release and transport of radionuclides from various types of wastes, including isotopic exchange between the aqueous and vapor phases. Recommend experimental work, design changes, or calculations to assure containment of gaseous radionuclides if transport 1 : significant in this form. 
Many of the data needs mentioned in Items 1. and 2. above are currently being supplied by the experimental program at Los Alamos. 11 others, such as the solubility of Cs or Tc (under oxidizing conditions), may not be experimentally determined, but may be assumed to have worst-case values (no solubility limits). Decisions concerning the level of experimental effort required to provide a data base for these important waste elements will be made as the site-characterization program develops.

\section{REFERENCES}

1. A. G. Croff and C. W. Alexander, "Decay Characteristics of Once-Through LWR and LMFBR Spent Fuels, High-Level Wastes, and Fuel Assembly Structural Material Wastes," Dak Ridge National Laboratory report ORNL/TM-7431 (November 1980).

2. R. G. Baxter, "Description of Defense Waste Processing Facility Reference Waste Form and Canister, "Savannah River Plant report DP-1606, Rev. 1 (August 1983).

3. P. D. O'Brien, "Preliminary Reference Waste Descriptions for a Repository at Yucca Mountain. Nevada, "Sandia National Laboratories report SAND83-1805 (July 1984).

4. S. N. Storch and B. E. Prince, "Assumptions and Ground Rules Used in Nuclear Waste Projections and Source Term Data, "Office of Nuclear Waste Isolation report ONWI-24 (September 1979).

5. Environmental Protection Agency, "40 CFR Part 191, Environmental Standards for the Management and Disposal of Spent Nuclear Fuel, High-Level, and Transuranic Radioactive Wastes, ". Federal Register, Vol. 50, No. 182 (September 29, 1985), pp. 38066-38089.

6. J. F. Kerrisk, "S.lubility Limits on Radionuclide Dissolution at a Yucca Mountain Repository," Los Alamns National Laboratory report LA-9995-MS (May 1984).

7. A. E. Ogard and J. F. Kerrisk, "Groundwater Chemistry Along Flow Paths Between a Proposed Repository Site and the Accessible Environment," Los Alamos National Laboratory report LA-10188-MS (November 1984).

8. H. Nitsche and N. Edelstein, "Determination of the Solubilities and Somplexation of Waste Radionuclides Pertinent to Geologic Oisposal at the Ne:vada Tuff Site," Lawrence Berkeley Laboratory repor'c LBL-18900 (January 1985).

9. P. Montazar and W. Wilson, "Conceptual Hydrologic Model of Flow in the Unsaturated Zone, Yucca Mountain, Nevada," US Geological Survey WaterResources Investigations report $84-4345$ (1984). 
10. Nuclear Regulatory Commtssion, "10 CFR Part 60, Disposal of High-Level Radioactive Wastes in Geologic Repositories, Technical Criteria," Federal Reg1ster. Vol. 48, No. 120 (June 21, 1983), pp. 28 194-28 229.

11. W. R. Dantels, K. Wolfsberg, R. S. Rundberg, A. E. Ogard, J. F. Kerrisk, C. J. Duffy, et al., "Summary Report on the Geochemlstry of Yucca Mountain and Environs, "Los Alamos National Laboratory report LA-9328-MS (December 1982).

12. G. Friedilander and J. W. Kennedy, Nuclear and Radiochemistry (John Wiley and Sons. Inc., New York, 1955), pp. 127-135. 